\title{
ע Toimeentulotuen asiakkaiden terveyspalvelujen käyttö Helsingissä vuonna 2014
}

Huonossa sosioekonomisessa asemassa olevat sairastavat muita enemmän ja heillä on tyydyttymätöntä terveyspalvelujen tarvetta, vaikka he käyttävät runsaasti perusterveydenhuollon palveluja (I). Hyvin toimeentulevat käyttävät tutkimusten mukaan erikoislääkäripalveluja yleisemmin kuin alemmat tuloryhmät $(20,21)$. Helsinkilaiisten toimeentulotukiasiakkaiden perusterveydenhuollon ja erikoissairaanhoidon käyttöä ei ole tutkittu. Tässä tutkimuksessa helsinkiläisten toimeentulotuen asiakkaiden $(\mathrm{N}=38434)$ sosiaali- ja terveysviraston tai Helsingin ja Uudenmaan sairaanhoitopiirin (HUS) erikoissairaanhoidon vuoden 2014 käynti- ja hoitojaksotietoja verrattiin muiden helsinkiläisten $(\mathrm{N}=40 \mathrm{I} 23 \mathrm{I})$ käynti- ja hoitojaksotietoihin ja toimeentulotuen asiakkuuden yhteyttä terveyspalvelujen käynteihin ja hoitojaksoihin analysoitiin käyttäen menetelmänä logistista regressioanalyysia ja Poisson-regressioanalyysia. Tulosten mukaan terveyspalveluja käyttäneillä toimeentulotuen asiakkailla oli ikävakioituna selvästi todennäköisemmin diagnosoitu sairaus sekä hampaiden reikïntymistä ja kiinnityskudosten sairauksia kuin niillä, jotka eivät olleet toimeentulotuen asiakkaita. Toimeentulotuen asiakkuus oli voimakkaasti yhteydessä lisääntyneisiin päihde- ja mielenterveyskäynteihin ja -hoitojaksoihin, perusterveydenhuollon käynteihin ja päirystysvastaanottokäynteihin sekä perusterveydenhuollon ja päivystyksen akuuttihoitojaksoihin. Sen sijaan toimeentulotuen asiakkuuden yhteys erikoislääkäritutkimuksiin ja suun terveydenhuollon käynteihin oli heikompi ja osassa erikoislääkäritutkimuksia toimeentulotuen asiakkaan käynti oli suhteellisesti epätodennäköisempi kuin niiden, jotka eivät olleet toimeentulotuen asiakkaita. Toimeentulotuen asiakkuus oli heikommin yhteydessä HUS:n käynteihin kuin sosiaali- ja terveysviraston perusterveydenhuollon käynteihin. Toimeentulotuen asiakkuus selitti miehillä käyntejä HUS:ssa vammojen ja myrkytysten, hermoston sairauksien ja infektioiden vuoksi ja naisilla sisäerityselinten ja ruoansulatuselinten sairauksien sekä infektioiden vuoksi. Toimeentulotuen asiakkuus selitti HUS:n hoitojaksoja sisäerityselinten, ihon ja ihonalaiskudoksen, hermoston ja hengityselinten sairauksien vuoksi.

\section{ASIASANAT: terveyspalvelujen käyttö, toimeentulotuki, terveyserot}

\section{JUHA NYMAN, MARTTI ARFFMAN, ILMO KESKIMÄKI}

\section{JOHDANTO}

Terveyspolitiikan tavoite on ollut 1980-luvulta alkaen terveyserojen kaventaminen ja eri väestöryhmien tasa-arvoinen ja tarpeenmukainen hoitoon pääsy terveyspalveluihin. Tavoitetta ei ole kuitenkaan saavutettu: heikossa sosiaalisessa asemassa olevat käyttävät terveyspalveluja vähem- män kuin hyvin toimeentulevat, vaikka heillä on huonompi terveys (1).

Oikeus toimeentulotukeen syntyy, jos henkilön tulot ovat pienet. Toimeentulotuen asiakkaista joka toinen on pitkäaikaistyötön (2). Helsinkiläisistä toimeentulotuen asiakkaista kävi töissä vuonna 2014 vain viisi prosenttia. Noin 
kolme neljäsosaa oli yksinasuvia, ja heistä neljä viidesosaa oli köyhiä, eli heidän tulonsa olivat alle $60 \%$ keskitulosta. Helsingissä $42 \%$ toimeentulotuen saajista tarvitsi tukea koko vuoden tai lähes koko vuoden. Toimeentulotuen perusosa vuonna 2014 yksinasuvalla oli 480 euroa ja yksinhuoltajalla 528 euroa kuukaudessa $(3,4)$.

Toimeentulotukiasiakkailla terveysongelmat ja alkoholihaitat ovat yleisiä (5). Kun verrataan alimman tuloviidenneksen alkoholisyistä johtuvaa kuoleman riskiä (Risk Ratio) ylimmän tuloviidenneksen kuolemanriskiin, on tulos vakioitavista taustamuuttujista riippuen 1,6-3,8(6). Vuonna 2014 toimeentulotuen asiakkaita Helsingissä oli 49940 ja toimeentulotukea saaneissa kotitalouksissa asui 65186 henkilöä eli 10,6 \% Helsingin väestöstä (3).

Erityisesti pitkäaikainen toimeentulotuen asiakkuus kokoaa yhteen monin tavoin vähäosaisia henkilöitä. Aiempien tutkimusten mukaan vähäosaiset, heikossa yhteiskunnallisessa asemassa olevat käyttävät terveydenhuollon palveluja keskimäärin vähemmän kuin muu väestö, kun otetaan huomioon henkilön tarpeet $(1,7,8)$. Helsingissä on ollut useita vuosikymmeniä muuta maata suurempi kuolleisuus ja lyhyempi elinajanodote (9). Toimeentulotukea saavien lukumäärä on Helsingissä suuri, joten tietoja heidän terveyspalvelujen käytöstään tarvitaan sosiaali- ja terveystoimen palvelujen suunnittelussa ja arvioinnissa. Terveyserojen kaventaminen on Helsingin sosiaali- ja terveysviraston toiminnan keskeinen tavoite (10). Tämän tutkimuksen tarkoituksena on selvittää, eroaako toimeentulotuen asiakkaiden perusterveydenhuollon ja erikoissairaanhoidon palvelujen käyttö muun väestön julkisen terveydenhuollon palvelujen käytöstä. Tulokset nostavat esiin toimeentulotukiasiakkaat, joiden terveyspalvelujen saantiin olisi kiinnitettävä nykyistä enemmän huomiota.

\section{TOIMEENTULOTUKI JA SAIRASTAVUUS}

Alueellisessa terveys- ja hyvinvointitutkimuksessa vastaajilta kysyttiin vastaajien terveydentilaa, onko heillä ollut 12 kuukauden aikana lääkärin toteamia tai hoitamia sairauksia. Tulosten mukaan toimeentulotukiasiakkailla oli muuta väestöä enemmän mielenterveysongelmia, kohonnutta verenpainetta, sepelvaltimotautia, selkäsairauksia, syöpäsairauksia ja keskimääräistä huonommaksi koettu terveys, kun tulokset ikävakioitiin
(11). Nuorisotutkimusseuran julkaiseman tutkimuksen mukaan 22-29-vuotiaista toimeentulotuen asiakkaista $46 \%$ :lla oli viiden vuoden ajanjaksolla ollut vamma tai myrkytys ja $57 \%$ :lla psykiatrisia sairauksia. Lisäksi toimeentulotuen asiakkailla oli muita saman ikäisiä yleisemmin ollut ruoansulatuselinten, hengityselinten, verenkiertoelinten, tuki- ja liikuntaelinten ja sidekudosten sairauksia sekä tartunta- ja loistauteja. Mitä pidempään toimeentulotuen varassa ihminen oli elänyt, sitä todennäköisempi sairaus oli (12).

Toimeentulotukea saavat ovat alimmassa tuloviidenneksessä. Alimmassa tuloviidenneksessä olevista 15,7 \%:lla ja ylimmässä tuloviidenneksessä 10,9\%:lla oli Terveys 2000 -tutkimuksen mukaan ollut jokin sairaus, johon vastaaja ei oman ilmoituksensa mukaan ollut saanut hoitoa. Yleisimpiä hoitamattomia sairauksia olivat tuki- ja liikuntaelimistön, verenkiertoelimistön, hermoston ja aistimien sekä ruoansulatuselimistön sairaudet (13). Vuosina 1992-2008 kerätyssä aineistossa ennenaikaisen kuoleman riski oli 25-59-vuotiailla alimmassa tuloviidenneksessä 98/100 000 asukas ja ylimmässä tuloviidenneksessä 40/100 000 asukas (14).

Elinajanodote on väestössämme keskimäärin pidentynyt, mutta sosiaaliryhmien väliset terveyserot ovat lisääntyneet 1990-luvulla. Ehkäistävissä oleva kuolleisuus on pienentynyt väestössä erityisesti sydän -ja verisuonitautikuolemien vähenemisen johdosta, mutta kuolleisuus on pienentynyt vähemmän alimmassa sosioekonomisessa ryhmässä kuin ylimmässä sosioekonomisessa ryhmässä (7). Kahden alimman tuloviidenneksen kuolleisuusero verrattuna ylimpään tuloviidennekseen on suuri varsinkin miehillä. Terveyserojen kasvu johtuu erityisesti kuolleisuudesta alkoholisyihin (15).

Sosioekonomisten ryhmien terveyseroja koskevissa tutkimuksissa tulokset näyttävät osin riippuvan siitä, onko tutkimuksessa terveyden indikaattorina ollut itsearvioitu terveys, todettu krooninen sairaus tai elinajanodote. Kun verrattiin, miten sosioekonomisten ryhmien itsearvioidu terveys erosi Euroopan maissa, Suomi kuului yhdeksän muun maan joukossa vähäisimpien terveyserojen ryhmään (16). Yhdentoista Euroopan maan vertailussa itsearvioidun terveyden ja sairastavuuden osalta sosioekonomisten ryhmien välinen eriarvoisuus ei ollut Suomessa muita maita suurempaa. Kaikissa vertailun maissa oli 
sairauden ja kuoleman riski suurempi alimmissa sosioekonomisessa ryhmissä kuin ylemmissä sosioekonomisissa ryhmissä. Ammattiasema oli yhdentoista Euroopan maan vertailussa voimakkaimmin yhteydessä kuolleisuuteen suomalaisilla miehillä (17).

\section{TOIMEENTULOTUEN ASIAKKUUS JA TERVEYS- PALVELUJEN KÄYTTÖ}

Vuoden aikana vähintään kerran terveyskeskuksessa lääkärin vastaanotolla käy suomalaisista vähän alle puolet mutta toimeentulotuen asiakkaista noin kolme neljäsosaa. Vuoden aikana yksityislääkärin vastaanotolla käy toimeentulotuen asiakkaista noin $14 \%$ ja muusta aikuisväestöstä noin $30 \%$. Työterveyshuollossa käy toimeentulotuen asiakkaista noin $24 \%$ ja muusta aikuisväestöstä noin $41 \%$ (11).

Yhdessätoista maassa tehdyn tutkimuksen tulosten mukaan pienituloisilla potilailla oli suhteellisesti enemmän lääkärikäyntejä sekä vuodeosastohoitopäiviä kuin hyvätuloisilla. Mutta kun ikä, sukupuoli, itsearvioitu terveys ja krooninen sairaus oli vakioitu, lääkäripalveluja käyttivätkin enemmän hyvätuloiset kuin pienituloiset. Suomessa saatujen tulosten mukaan hoidon tarpeen ollessa sama, hyvätuloisilla oli henkilöä kohti pienituloisia enemmän erikoislääkärikäyntejä sekä lääkärin vastaanottokäyntejä yhteensä. Vuodeosastohoidon käyttöä tarvevakioituna tulot eivät kuitenkaan selittäneet. Mitä suuremmat tulot potilaalla olivat, sitä suuremmat olivat todelliset hoidon kustannukset (1). Suomessa tehdyn tutkimuksen mukaan ikävakioidut potilaskohtaiset hoitopäiväkustannukset olivat yli viidenneksen korkeammat ylimmässä tuloviidenneksessä kuin alimmassa tuloviidenneksessä. Tuloviidennesten välinen ero oli pienempi sisätautiosastoilla kuin kirurgisilla osastoilla (18). Erään kotimaisen tutkimuksen mukaan pienituloiset käyttivät ikä- ja sukupuolivakioituna suhteellisesti muita tuloryhmiä enemmän somaattisen erikoissairaanhoidon vuodeosastohoitoa (19).

Kymmenessä Euroopan unionin maassa tehtiin vertailututkimus, jonka tulosten mukaan vain Suomessa varakkain väestönosa kävi tarvevakioituna suhteellisesti pienituloisia enemmän sekä erikoislääkärillä että yleislääkärillä. Tutkimuksessa työterveyshuollon käynnit ja yksityislääkärikäynnit oli laskettu yleislääkärikäynteihin (20). Samankaltainen tulos saatiin myös yhdek- säntoista OECD-maan vertailussa: sen mukaan perusterveydenhuollon lääkärivastaanottojen käyttö oli tarvevakioituna varsin samanlaista eri sosioekonomisissa ryhmissä muissa vertailun maissa paitsi Suomessa, jossa hyvätuloiset käyttivät perusterveydenhuollon lääkärivastaanottoa tarvevakioituna suhteellisesti pienituloisia enemmän. Erikoislääkärivastaanottoa hyvätuloiset käyttivät kaikissa vertailumaissa pienituloisia suhteellisesti enemmän. Mitä helpompaa oli hakeutua yksityislääkärivastaanotolle, sitä hyvätuloisia suosivampi terveydenhuolto oli (21).

Suomessa tehdyn tutkimuksen mukaan alimman tuloryhmän todennäköisyys päästä kirurgiseen toimenpiteeseen oli ylintä tuloryhmää pienempi kuudessa toimenpiteessä seitsemästä; kaikkineen tarkasteltuja toimenpiteitä oli seitsemän. Sosioekonomiset erot toimenpiteisiin pääsyssä ovat naisilla miehiä pienemmät (22). Toisen tutkimuksen mukaan vuosina 1992-2003 useita kirurgisia toimenpiteitä tehtiin ylimmille tuloryhmille suhteellisesti yleisemmin kuin alimmille tuloryhmille. Sepelvaltimoiden verenkierron palauttavia toimenpiteitä tehtiin jakson loppupuolella alimpien tuloryhmien naisille kuitenkin suhteellisesti yleisemmin kuin ylempien tuloryhmien naisille. Näissä toimenpiteissä yksityissektorin osuus lähetteistä oli muita toimenpiteitä selvästi pienempi, vain seitsemän prosenttia (23).

Vuoden aikana noin viidennes väestöstä käy terveyskeskushammaslääkärissä. Ylimpään tuloviidennekseen kuuluvat käyvät muita säännöllisemmin hammashoidossa, ja yleisin hoitopaikka heillä on yksityishammaslääkärin vastaanotto (13). Helsingissä, Espoossa ja Vantaalla tehdyn tutkimuksen mukaan väestöstä 17,2 \%, mutta toimeentulotukea saaneista $20,5 \%$ ei ollut käynyt hammashoidossa viiden vuoden aikana. Ylimmässä tulokymmenyksessä 9,3\% ja alimmassa tulokymmenyksessä $30,6 \%$ ei ollut viiteen vuoteen käynyt hammashoidossa. Verrattaessa toimeentulotukea saavia samassa tuloluokassa olevaan muuhun väestöön toimeentulotuki oli yhteydessä suun terveydenhuollon käynnin todennäköisyyden lisääntymiseen 70 \%:lla. Mutta ilman tulojen vakiointia toimeentulotuen asiakkailla oli $20 \%$ suurempi todennäköisyys jäädä ilman hammashoidon käyntiä verrattuna muuhun väestöön ja $80 \%$ suurempi todennäköisyys jäädä ilman hampaiden tarkastusta viiden vuoden aikana (24). Huomattavasti pienem- 
pi osuus tutkimusjoukosta ei ollut käynyt suun terveydenhuollossa 24 Euroopan maan vertailututkimuksessa, jonka tulosten mukaan kaikissa osallistujamaissa keskimäärin $8 \%$ aikuisväestöstä ei ollut käynyt hammashoidossa vuoden aikana. Suomessa miehistä 3,3\% ja naisista 2,7\% ei ollut käynyt hammashoidossa. Käynnin puuttumista selitti miessukupuoli ja alhainen koulutustaso (8).

\section{TUTKIMUSONGELMAT}

Aikaisemmista tutkimuksista on käynyt ilmi, että pienituloisuus on yhteydessä sairastavuuteen ja lisääntyneeseen julkisten terveyspalvelujen käyttöön. Aiempien tutkimusten mukaan terveydenhuollon ja suun terveydenhuollon käyntejä on maassamme kuitenkin tarvevakioituna ylimmillä tuloryhmillä selvästi yleisemmin ja enemmän kuin alimmilla tuloryhmillä. Tämä tuloryhmien välinen ero on suurempi erikoissairaanhoidossa kuin perusterveydenhuollossa $(1,20,21)$. Ilman tarvevakiointia tutkittu tuloryhmien välinen ero erikoissairaanhoidon toimenpiteiden yleisyydessä on kaventunut tai säilynyt ennallaan viime vuosina ja vaihtelee toimenpiteittäin $(23,25)$. Vuodeosastohoitoa pienituloiset käyttävät hyvätuloisia enemmän (19). Tämän tutkimuksen tavoitteena on selvittää, eroaako toimeentulotuen asiakkaiden julkisten terveyspalvelujen käyttö muun väestön palvelujen käytöstä.

Tutkimuskysymykset ovat seuraavat:

Miten toimeentulotuen asiakkaiden perusterveydenhuollon käyttö ja suun terveydenhuollon käyttö eroavat muun väestön perusterveydenhuollon ja suun terveydenhuollon käytöstä?

Miten toimeentulotuen asiakkaiden erikoissairaanhoidon käyttö eroaa muun väestön erikoissairaanhoidon käytöstä?

\section{AINEISTO JA MENETELMÄT}

Tässä tutkimuksessa käytettiin Helsingin kaupungin sosiaali- ja terveysvirastossa sekä Helsingin ja Uudenmaan sairaanhoitopiirissä (HUS) koottua aineistoa helsinkiläisten tekemistä perusterveydenhuollon ja erikoissairaanhoidon käynneistä ja hoitojaksoista vuodelta 2014. Aineistoon yhdistettiin henkilötunnusten avulla sosiaali- ja terveysviraston toimittama tieto vuonna 2014 toimeentulotukea saaneista. Tarkempaan analysointiin otettiin mukaan ne vähintään 15 -vuotiaat helsinkiläiset, jotka olivat käyttäneet vuon- na 2014 sosiaali- ja terveysviraston tai HUS:n terveyspalveluja. Toimeentulotuen asiakkaista analyyseissa olivat mukana ne, jotka olivat käyttäneet sosiaali- ja terveysviraston tai HUS:n palvelua vuoden aikana. Palvelua käytti $77 \%$ toimeentulotuen asiakkaista ja $85 \%$ vähintään 15 -vuotiaista helsinkiläisistä, jotka eivät olleet toimeentulotuen asiakkaita. Aineistossa eivät olleet mukana neuvolatyö, koulu- ja opiskeluterveydenhuolto, äitiysneuvonta ja kotisairaanhoito.

Selitettävinä muuttujina malleissa olivat kaksiarvoiset muuttujat käynneistä ja hoitojaksoista sekä käyntien ja hoitojaksojen lukumäärä vuoden 2014 aikana. Helsingin sosiaali -ja terveysviraston palveluista selitettävinä olivat käynnit kahdeksalla avohoidon vastaanotolla, jotka olivat

- terveysasemien avosairaanhoidon lääkärin vastaanotto

- terveysasemien avosairaanhoidon hoitajan vastaanotto

- aikuisten terveyskeskuspäivystys

- perustason kirurginen päivystys

- sisätautien poliklinikka

- psykiatrian poliklinikka

- selviämisvastaanotto

- päihdetyön vastaanotto terveysasemilla.

Aikuisten terveyskeskuspäivystyksessä käynnit olivat sekä lääkärikäyntejä että hoitajakäyntejä. Perustason kirurgisessa päivystyksessä ja sisätautien poliklinikalla käynnit olivat lähes yksinomaan lääkärikäyntejä. Psykiatrian poliklinikalla käynnit olivat lääkärikäyntejä, hoitajakäyntejä, sosiaalityöntekijäkäyntejä tai psykologikäyntejä. Selviämisvastaanotolla ja päihdetyön vastaanotolla terveysasemilla käynnit olivat hoitajakäyntejä.

Hoitojaksoista selitettävinä olivat kuntoutuksen laitoshoito, päivystyksen akuuttihoitojaksot, perusterveydenhuollon akuuttihoitojaksot ja akuuttipsykiatrian hoitojaksot. Helsingin sosiaali- ja terveysviraston erikoislääkärivastaanottokäynneistä selitettävinä olivat kardiologinen vastaanotto, rasitus-EKG vastaanotto, elektiivinen kardioversio, kaikukardiografiat ECHO, gastroenterologinen vastaanotto, gastroskopiavastaanotto, colonoskopiavastaanotto ja diabetesvastaanotto.

Helsingin sosiaali- ja terveysvirasto rahoittaa HUS:n helsinkiläisille tuottamat erikoissai- 
raanhoidon palvelut. Helsingin ja Uudenmaan sairaanhoitopiirin hoidollisista pääryhmistä selitettävinä olivat hoitokäynnit ja hoitojaksot seuraavista: hermoston sairaudet, hengityselinten sairaudet, verenkiertoelinten sairaudet, ruoansulatuselinten sairaudet, sisäerityselinten sairaudet, tuki- ja liikuntaelinten sairaudet, ihon ja ihonalaiskudoksen sairaudet, aineenvaihduntaja umpierityssairaudet, infektiosairaudet, mielenterveyden sairaudet, vammat ja myrkytykset ja muu terveyspalvelujen käytön syy.

Selittäjinä malleissa käytettiin kaksiarvoista toimeentulotuen asiakkuus -muuttujaa sekä sukupuoli- ja ikämuuttujia. Asiakkaan ikä luokiteltiin kolmeluokkaiseksi muuttujaksi 15-49 vuotta, 50-64 vuotta sekä 65 vuotta ja sitä vanhemmat. Toimeentulotuen asiakkaat olivat nuorempia ja useammin miehiä kuin ne terveyspalveluja käyttäneet, jotka eivät olleet toimeentulotuen asiakkaita. Malleihin, joissa selitettiin terveyspalvelujen käyttöä perusterveydenhuollon tai erikoissairaanhoidon yksiköissä, sisällytettiin ikäryhmän ja toimeentulotuen asiakkuuden sekä sukupuolen ja toimeentulotukiasiakkuuden yhdysvaikutustermit. Yhdysvaikutustermin mukaanotto paransi mallien sopivuutta havaintoaineiston kanssa.

Kuvailevassa analyysissa käytettiin osuuksia ja keskiarvoja. Toimeentulotuen asiakkuuden ja perusterveydenhuollon sekä erikoissairaanhoidon käytön yhteyttä tutkittiin logistisen regressioanalyysin avulla, kun selitettiin, onko henkilöllä ainakin yksi terveyspalvelujen käyttöä kuvaava käynti tai hoitojakso vuonna 2014. Kun tarkasteltiin käyntien tai hoitojaksojen lukumäärää, käytettiin Poisson-regressioanalyysiä.

Lisäksi tarkasteltiin, kuinka paljon toimeentulotukiasiakkailla ja muilla terveyspalvelujen käyttäjillä esiintyi 49 yleisimmän ICD-10 diagnoosiryhmän sairauksia ikävakioituna. Yleisimmät sairaudet saatiin sosiaali- ja terveysviraston sekä HUS:n potilasrekisterin vuoden 2014 käyntitiedoista. Diagnoosiryhmään poimitaan päädiagnoosit. Sivudiagnooseja vastaanotoilla merkitään selvästi päädiagnoosia harvemmin. Lukumääräisesti eniten käyntejä oli 25 terveysasemalla. Vuonna 2014 diagnoosi (ICD-10) puuttui $8,1 \%$ :ssa terveysasemien avosairaanhoidon lääkärivastaanottokäynneistä ja käyntisyy (ICD-10 tai ICPC2) puuttui 11,5\%:ssa muista hoitokäynneistä. Taustamuuttujista asumismuo- to, siviilisääty ja työtilanne olivat tiedossa ainoastaan toimeentulotuen asiakkaista, joten niitä ei käytetty analyysissa hyväksi. Tuloksissa esitetään muuttujien luokkien ristitulosuhde ja riskisuhde sekä näiden $95 \%$ :n luottamusväli. Tilastolliset analyysit tehtiin käyttäen SAS-EG 5.1 -tilasto-ohjelmaa.

Helsingin sosiaali- ja terveysviraston virastopäällikkö myönsi tutkimukselle tutkimusluvan 12.6.2015 (\$ 117). Tutkimus on rekisteritutkimus, jossa tutkimusaineistoa käsiteltiin henkilön tunnistetiedot salattuina eikä eettisen toimikunnan käsittelyä siten edellytetty.

\section{TULOKSET}

\section{TUTKIMUSAINEISTON KUVAILEVAT TIEDOT}

Terveyspalveluja käyttäneistä toimeentulotuen asiakkaista oli miehiä 49,8 \% ja niistä terveyspalveluja käyttäneistä, jotka eivät olleet toimeentulotuen asiakkaita, miehiä oli 46,4\%. Vuoden 2014 lopussa miesten osuus Helsingin väestöstä oli 47,2 \% (26). Toimeentulotuen asiakkaista miesten osuus oli 2,6 prosenttiyksikköä suurempi kuin Helsingin väestössä, ja niistä terveyspalveluja käyttäneistä, jotka eivät olleet toimeentulotuen asiakkaita, miesten osuus oli 0,8 prosenttiyksikköä pienempi kuin Helsingin väestössä.

Toimeentulotuen asiakkaat olivat ikärakenteeltaan nuorempia kuin ne terveyspalveluja käyttäneet, jotka eivät olleet toimeentulotuen asiakkaita. Terveyspalveluja käyttäneistä toimeentulotuen asiakkaista 15-49-vuotiaita oli $70,3 \%, 50-64$-vuotiaita $22,7 \%$ ja 65 vuotta täyttäneitä ja sitä vanhempia 7,0\%. Niistä terveyspalveluja käyttäneistä, jotka eivät olleet toimeentulotuen asiakkaita, 15-49-vuotiaita oli 53,4 \%, 50-64-vuotiaita $18,9 \%$ ja 65 vuotta täyttäneitä ja sitä vannhempia $27,7 \%$.

Toimeentulotukea saaneista yksinasuvia miehiä oli $46 \%$, yksinasuvia naisia $31 \%$, yksinhuoltajia $11 \%$ ja pariskuntia $12 \%$. Vuonna 2014 toimeentulotuen saajista tukea sai 1-3 kuukautta $28 \%$, 4-9 kuukautta $30 \%$ ja 10-12 kuukautta $42 \%$. Toimeentulotuen asiakkaista $56 \%$ oli työttömiä tai lomautettuja, $14 \%$ eläkkeellä ja $10 \%$ opiskelijoita. Loput tuen saajista olivat työssä tai vanhempainvapailla. Toimeentulotuen asiakkaista asunnottomana oli vuoden aikana ollut 2664 henkeä eli 5,3\%. Toimeen- 
tulotukiasiakkaista naimattomia, eronneita tai leskiä oli $81 \%$, kun koko Helsingin 15 vuotta täyttäneestä väestöstä heitä oli $65 \%$. Toimeentulotukiasiakkaista oli muita kieliä kuin suomea tai ruotsia äidinkielenään puhuvia $24 \%$, kun Helsingin koko väestöstä heitä oli 12,8 \% (26).

Toimeentulotukiasiakkuus oli alueellisesti keskittynyt, sillä toimeentulotuen asiakkaista 7872 asui Mellunkylän, Vuosaaren tai Herttoniemen peruspiireissä, mikä on $12,6 \%$ näiden kolmen peruspiirin 15 vuotta täyttäneestä väestöstä. Sitä vastoin Länsi-Pakilassa, Tuomarinkylässä ja Kulosaaressa asui yhteensä vain 242 toimeentulotuen asiakasta, mikä on 2,0\% näiden kolmen peruspiirin 15 vuotta täyttäneestä väestöstä.

\section{TOIMEENTULOTUKI JA SAIRASTAVUUS}

Vuoden 2014 aikana sosiaali- ja terveysvirastossa tai HUS:ssa käyneiden tai hoitojaksolla olleiden toimeentulotuen asiakkaiden diagnoosiryhmien mukaista sairastavuutta verrattiin muiden 15 vuotta täyttäneiden sosiaali- ja terveysviraston tai HUS:n yksiköissä käyneiden sairastavuuteen. Analyysiin otettiin mukaan diagnoosiryhmät, jotka olivat esiintyneet Helsingin sosiaali- ja terveysviraston ja HUS:n potilastietojärjestelmässä vuoden aikana yleisimmin.

Henkilöllä saattoi olla useita diagnooseja, jotka oli saatu käynneillä tai hoitojaksoilla terveydenhuollon eri yksiköissä. Diagnoositieto oli dikotominen 0/1-muuttuja. Muodostettiin logistinen regressiomalli selitettävänä dikotominen diagnoosimuuttuja 0/1 ja selittäjinä toimeentulotuen asiakkuus / ei toimeentulotuen asiakkuutta. Toimeentulotuen asiakkaat ja muut 15 vuotta täyttäneet terveyspalvelujen käyttäjät saatettiin iältään vertailukelpoisiksi lisäämällä malliin ikäryhmä-muuttuja.

Kun tulokset ikävakioitiin, oli toimeentulotuen asiakkailla lähes kaikkia analyysissa olevia diagnoosiryhmän sairauksia yleisemmin kuin niillä, jotka eivät saaneet toimeentulotukea.

Ainoastaan kilpirauhasen sairauksiin, ihon ja ihonalaiskudoksen sairauksiin ja hyvän- ja pahanlaatuisiin kasvaimiin toimeentulotuen asiakkuus ei ollut yhteydessä. Toimeentulotuen asiakkuus oli yhteydessä lääkkeiden ja päihteiden aiheuttamiin elimellisiin aivo-oireyhtymiin ja käyttäytymisen häiriöihin $\operatorname{OR} 8,5$ (7,5-9,1), aikuisiän persoonallisuus- ja käyttäytymishäiriöihin OR 5,3 $(4,8-5,8)$ sekä skitsofreniaan ja harhaluuloisuushäiriöihin OR 3,4 (3,2-3,7). Toimeentulotuen asiakkuus oli voimakkaasti yhteydessä myös mielialahäiriöihin, stressiin liittyviin neuroottisiin ja somatomorfisiin (elimellisoireisiin) häiriöihin, bakteeri- ja infektiosairauksiin sekä selkäsairauksiin ja iho- ja ruoansulatuselimistön sairauksiin. (Kuvio 1.)

Vuoden 2014 aikana helsinkiläisiä sosiaalija terveysvirastossa kuolleiksi todettuja oli tutkimusaineistossa 1908 ja HUS:ssa 445. Toimeentulotuen asiakkaita kuoli vuoden aikana ikävakioituna suhteellisesti enemmän kuin niitä, jotka eivät olleet toimeentulotuen asiakkaita (sosiaalija terveysviraston yksiköissä OR 1,19 [0,991,44] ja HUS:ssa OR 3,13 [2,38-4,11]).

\section{SOSIAALI- JA TERVEYSVIRASTON PALVELUJEN KÄYTTÖ}

Jotain sosiaali- ja terveysviraston tai HUS:n palvelua oli käyttänyt $77 \%$ toimeentulotuen asiakkaista (38434 henkeä) ja $83 \%$ niistä, jotka eivät olleet toimeentulotuen asiakkaita (401231 henkeä). Toimeentulotuen asiakkaista vain sosiaali- ja terveysviraston palveluja käytti $47 \%$. Niistä terveyspalveluja käyttäneistä, jotka eivät olleet toimeentulotuen asiakkaita, vain sosiaali- ja terveysviraston palveluja käytti $51 \%$. Toimeentulotuen asiakkaista, vain HUS:n palveluja käytti $2 \%$. Niistä terveyspalveluja käyttäneistä, jotka eivät olleet toimeentulotuen asiakkaita, vain HUS:n palveluja käytti $7 \%$.

Vuonna 2014 helsinkiläisistä toimeentulotuen asiakkaista oli käynyt vähintään kerran avosairaanhoidon lääkärin vastaanotolla $74 \%$ (58\% vuonna 2011), hoitajan vastaanotolla $55 \%$ (48 \% vuonna 2011), aikuisten terveyskeskuspäivystyksessä $20 \%$ (16\% vuonna 2011) ja psykiatrian poliklinikalla $19 \%$ (13\% vuonna 2011). Jotakin sosiaali- ja terveysviraston terveyspalvelua oli toimeentulotuen asiakkaista käyttänyt $77 \%$ (75\% vuonna 2011). Niistä terveyspalveluja käyttäneistä 15 vuotta täyttäneistä, jotka eivät olleet toimeentulotuen asiakkaita, avosairaanhoidon lääkärin vastaanotolla oli käynyt 53,1\%, avosairaanhoidon hoitajan vastaanotolla 45,9\%, terveyskeskuspäivystyksessä 9,6\% ja psykiatrian poliklinikalla 4, $1 \%$.

Vuoden 2014 aikana perusterveydenhuollon akuuttihoitojaksolla oli $1,7 \%$ toimeentulotuen asiakkaista ja 1,4\% niistä, jotka eivät olleet toimeentulotuen asiakkaita. Päivystyksen akuuttihoitojaksolla oli 4,2\% toimeentulotuen 


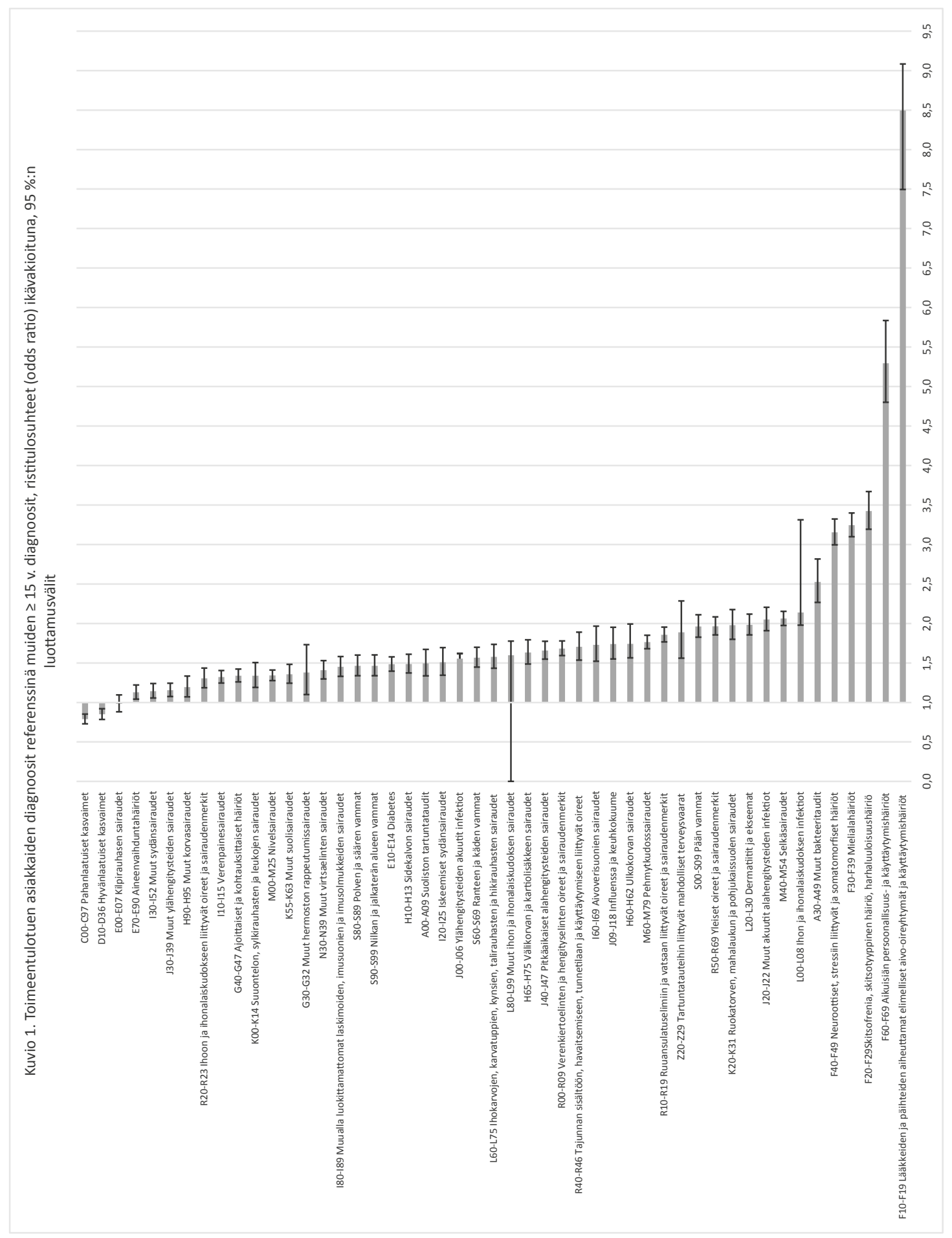


asiakkaista ja 2,6 \% muista 15 vuotta täyttäneistä asiakkaista. Kuntoutuksen laitoshoidossa oli $0,5 \%$ toimeentulotuen asiakkaista ja $0,4 \%$ niistä, jotka eivät olleet toimeentulotuen asiakkaita. Akuuttipsykiatrian hoitojaksolla oli 2,8 \% toimeentulotuen asiakkaista ja 0,3\% niistä, jotka eivät olleet toimeentulotuen asiakkaita.

Käyntien lukumäärien keskiarvot olivat seuraavat (suluissa niiden terveyspalveluja käyttäneiden keskiarvo, jotka eivät olleet toimeentulotuen asiakkaita). Käyntien keskiarvo toimeentulotuen asiakkailla terveysasemien avosairaanhoidon lääkärin vastaanotolla vuoden aikana oli 2,2 $(1,1)$, avosairaanhoidon hoitajan vastaanotolla 1,6 $(1,0)$, aikuisten terveyskeskuspäivystyksessä $0,4(0,2)$, suun terveydenhuollossa $1,2(1,1)$ ja psykiatrian poliklinikalla 2,0 $(0,4)$.

Tutkimuksessa kysyttiin, miten toimeentulotuen asiakkaiden perusterveydenhuollon käyttö eroaa muun väestön perusterveydenhuollon käytöstä. Tulosten mukaan toimeentulotuen asiakkuus oli ikä- ja sukupuolivakioituna yhteydessä perusterveydenhuollon käynteihin ja hoitojaksoihin. Selvimmin toimeentulotuen asiakkuus oli yhteydessä lisääntyneisiin terveysasemien päihdetyön, selviämisvastaanoton ja psykiatrian poliklinikkakäynteihin. Näissä palveluissa toimeentulotuen asiakkuuden ja palvelujen käytön yhteys oli jonkin verran suurempi naisilla kuin miehillä.

Toimeentulotuen asiakkuus oli yhteydessä akuuttipsykiatrian hoitojaksoon, perusterveydenhuollon akuuttihoitojaksoon, päivystyksen akuuttihoitojaksoon ja kuntoutuksen laitoshoidon hoitojaksoon. Perusterveydenhuollon sekä päivystyksen akuuttihoitojakson ja toimeentulotuen asiakkuuden yhteys oli suurempi miehillä ja nuoremmilla ikäryhmillä kuin naisilla ja vanhemmilla ikäryhmillä.

Toimeentulotukiasiakkuus oli kaikissa ikäryhmissä yhteydessä käyntiin ja hoitojaksoon sosiaali- ja terveysviraston perusterveydenhuollon eri yksiköissä. Toimeentulotuen asiakkuuden yhteys käyntiin ja hoitojaksoon oli voimakkain yksiköissä, joissa hoidettiin päihde- ja mielenterveysongelmista kärsiviä. Terveysasemien avosairaanhoidon hoitajavastaanotoilla ainoastaan 65 vuotta täyttäneillä ja sitä vanhemmilla, toimeentulotuen asiakkuus oli yhteydessä muita vastaavan ikäisiä epätodennäköisempään käyntiin. (Taulukko 1.)
Toimeentulotukiasiakkuus oli kaikissa ikäryhmissä yhteydessä käyntien ja hoitojaksojen kumulatiiviseen lukumäärään Helsingin sosiaali- ja terveysviraston yksiköissä. Yhteys oli voimakkain selviämisvastaanotolla ja terveysasemien päihdetyössä. Toimeentulotuen asiakkuus oli tilastollisesti merkitsevästi yhteydessä myös avosairaanhoidon hoitajakäyntien ja lääkärikäyntien, aikuisten terveyskeskuspäivystyskäyntien ja perustason kirurgisten päivystyskäyntien lukumäärään. 65 vuotta täyttäneillä ja sitä vanhemmilla toimeentulotuen asiakkuus oli erittäin voimakkaasti yhteydessä selviämisvastaanottokäyntien ja akuuttipsykiatrian hoitojaksojen lukumäärään. (Taulukko 2.)

Toimeentulotuen asiakkuudella oli ikä- ja sukupuolivakioituna yhteys diagnosoituihin hammaskariekseen sekä hampaan kiinnityskudosten ja hammasytimen sekä hampaan juuren kärkeä ympäröivien kudosten sairauksiin. Toimeentulotukiasiakkailla hammasytimen ja hampaan ympäröivien kudosten sairauksien ristitulosuhde oli OR 1,93 (1,80-2,00), hammaskarieksen ristitulosuhde OR 1,60 (1,55-1,65) ja hampaan kiinnityskudosten sairauksien ristitulosuhde OR 1,30 (1,24-1,37), kun referenssinä olivat ne terveyspalveluja käyttäneet, jotka eivät olleet toimeentulotuen asiakkaita. Kuitenkaan toimeentulotuen asiakkuus ei selittänyt suun terveydenhuollon käyntiä, sillä toimeentulotuen asiakkaiden suun terveydenhuollon käynnin ristitulosuhde ikä- ja sukupuoli vakioituina verrattuna niihin, jotka eivät olleet toimeentulotuen asiakkaita, oli 1,0.

Toimeentulotuen asiakkuus ei ollut yhteydessä sosiaali- ja terveysviraston erikoislääkärivastaanottokäyntiin tai toimeentulotuen asiakkuudella oli yhteys pienempään käynnin todennäköisyyteen kuin niillä, jotka eivät olleet toimeentulotuen asiakkaita. Toimeentulotuen asiakkuus ei ollut miehillä eikä naisilla missään ikäryhmässä yhteydessä kardiologisen vastaanottokäynnin eikä rasitus-EKG-vastaanottokäynnin toteutumiseen. Miehillä toimeentulotuen asiakkuus selitti vähentynyttä gastroenterologisen vastaanottokäynnin, colonoskopiavastaanottokäynnin, diabetesvastaanottokäynnin ja elektiivisen kardioversion todennäköisyyttä. Kuitenkin toimeentulotuen asiakkuus oli yhteydessä gastroskopiavastaanottokäyntiin. (Taulukko 3.) 


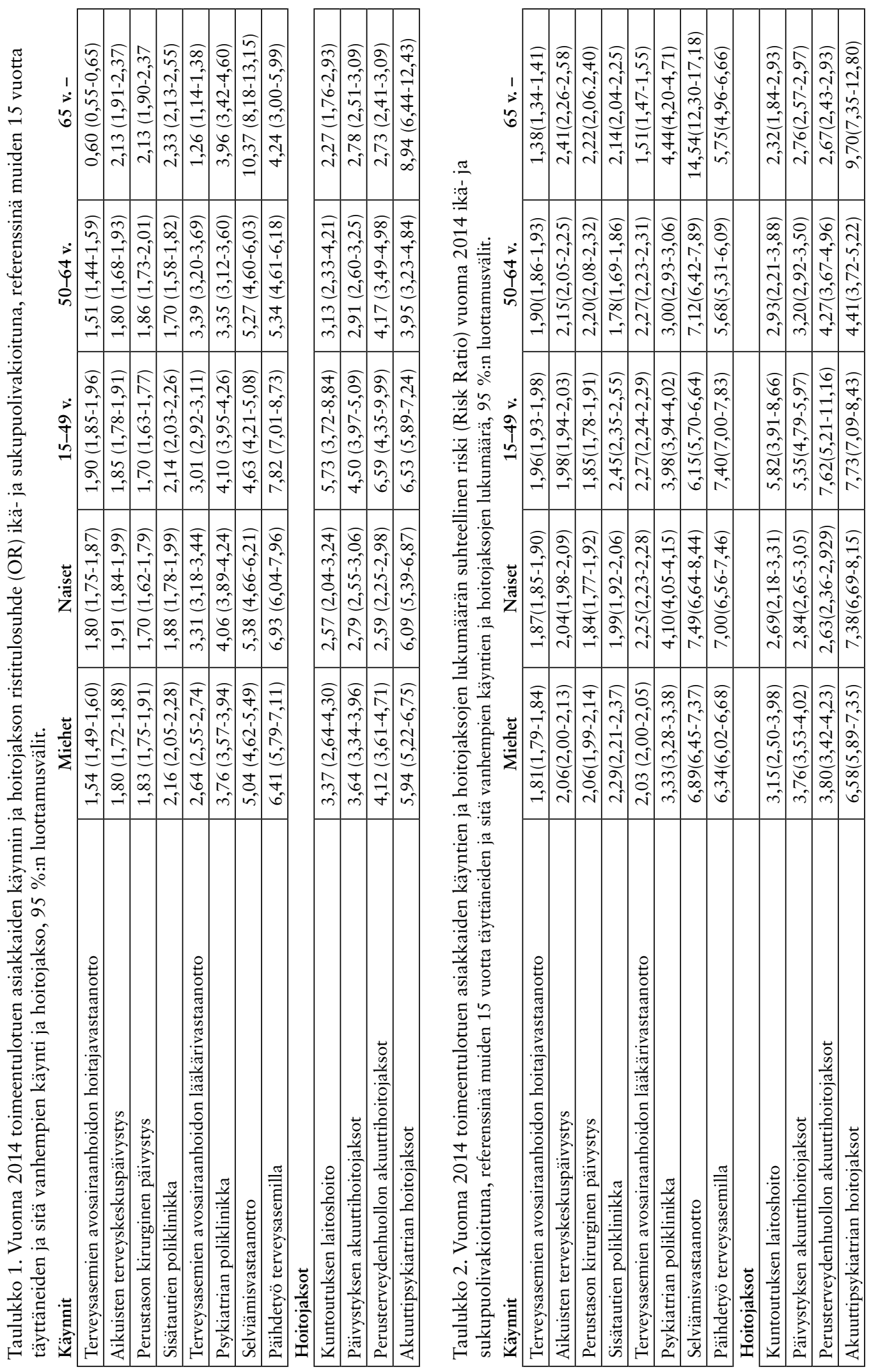


HELSINGIN JA UUDENMAAN SAIRAANHOITOPIIRIN HOIDOLLISTEN PÄÄRYHMIEN HOITOKÄYNNIT JA HOITOJAKSOT

Toimeentulotuen asiakkuus oli yhteydessä käyntiin ja hoitojaksoon hoidollisen pääryhmän ollessa mielenterveysongelma, vamma ja myrkytys, hermoston sairaus, tuki -ja liikuntaelinten sairaus, sisäerityselinten sairaus tai infektiosairaus. Lisäksi toimeentulotuen asiakkuus oli yhteydessä käyntiin ja hoitojaksoon hoidollisen pääryhmän ollessa ihon, ihonalaiskudoksen ja rinnan sairaus. Toimeentulotuen asiakkuus oli naisilla yhteydessä käyntiin ja hoitojaksoon hoidollisen pääryhmän ollessa ruoansulatuskanavan sairaus.

Toimeentulotuen asiakkuus ei ollut yhteydessä hoitokäyntiin eikä hoitojaksoon hoidollisen pääryhmän ollessa miehillä ruoansulatuselinten sairaus eikä naisilla aineenvaihdunta ja umpierityssairaus.

65 vuotta täyttäneillä ja sitä vanhemmilla toimeentulotuen asiakkuus oli yhteydessä käyntiin tai hoitojaksoon kaikissa muissa hoidollisten pääryhmien sairauksissa paitsi ruoansulatuselinten sairauksissa, aineenvaihdunta ja umpierityssairauksissa ja ihon, ihonalaiskudoksen ja rinnan sairauksissa. (Taulukko 4.)

HUS:n käyntien ja hoitojaksojen kumulatiiviseen lukumäärään toimeentulotuen asiakkuus oli miehillä ja naisilla yhteydessä mielenterveyden, hermoston ja sisäerityselinten sairauksissa sekä infektiosairauksissa. Toimeentulotuen asiakkuus oli naisilla yhteydessä käyntien ja hoitojaksojen lukumäärän kaikissa muissa hoidollisissa pääryhmissä paitsi aineenvaihdunta- ja umpierityssairauksissa.

15-49-vuotiailla toimeentulotuen asiakkuus oli yhteydessä käyntien ja hoitojaksojen lukumäärään muissa hoidollisissa pääryhmissä paitsi hengityselinten, verenkiertoelinten, ruoansulatuselinten sairauksissa sekä aineenvaihdunta ja umpierityssairauksissa. 65 vuotta täyttäneillä ja sitä vanhemmilla toimeentulotuen asiakkuus oli yhteydessä kaikkien muiden hoidollisten pääryhmien käyntien lukumäärään paitsi ihon, ihonalaiskudoksen ja rinnan sairauksissa, aineenvaihdunta ja umpierityssairauksissa sekä tuki- ja liikuntaelinten sairauksissa. (Taulukko 5.)

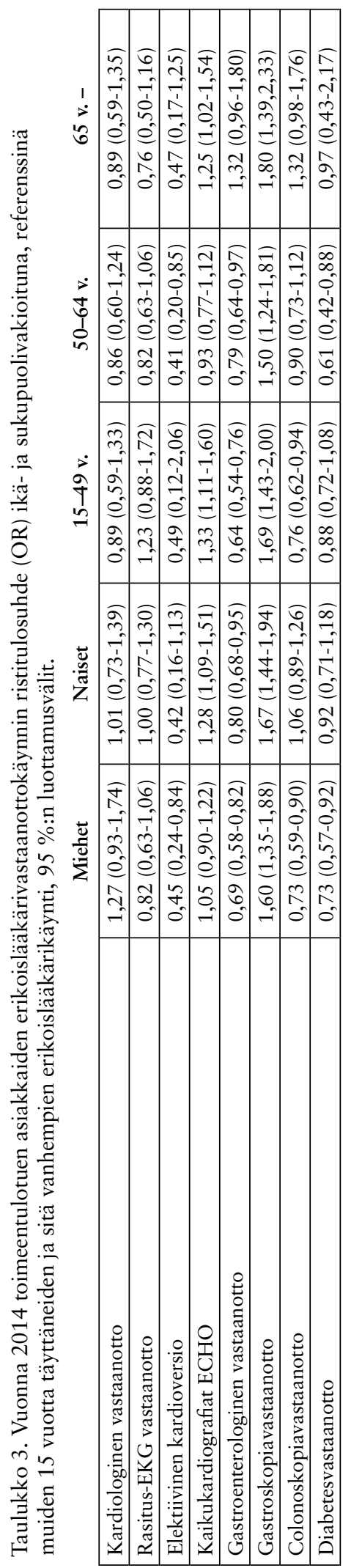




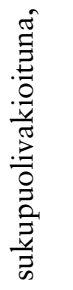

. $\underline{\text { I }}$

:

징

号

을 :

요

종

뭉

.

寻号

हี

ㄷำ

छ

है

$\frac{\pi}{2} \cdot \frac{0}{2}$

ज

.

훙

응

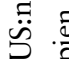

沗

홍

(⿻)

亲:

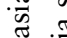

ี 몬

을

㻤:

ह

$\stackrel{\circ}{\circ}$

은

뫃

$>$ 更

$\dot{+}:$

辛

ฮั

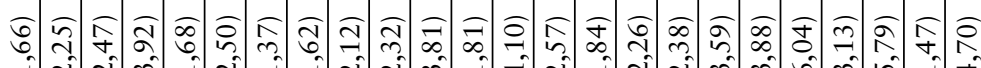

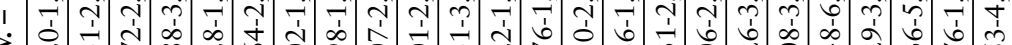

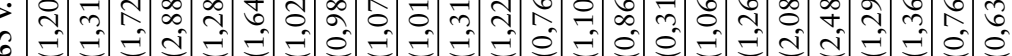

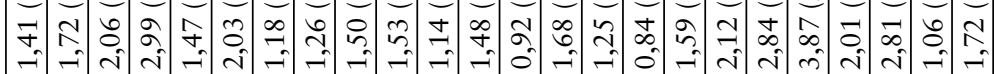

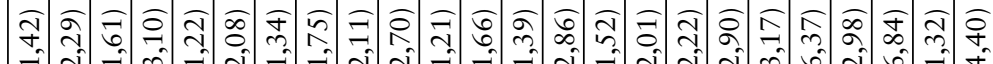
ए)

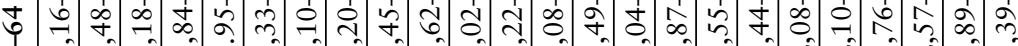

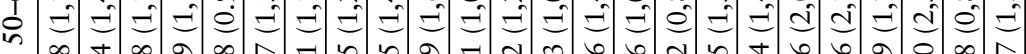

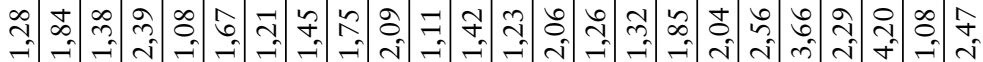

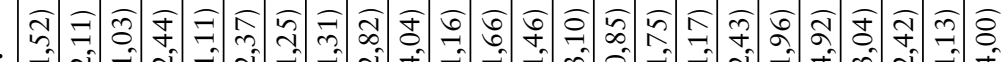

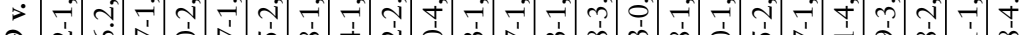
वे $m$ l

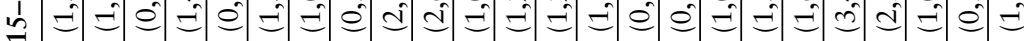
F

के $\rightarrow \rightarrow-1$ री $\rightarrow$ री 造

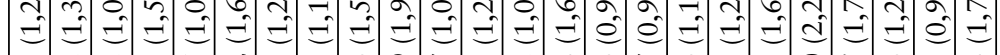

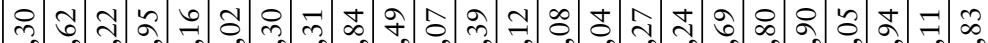

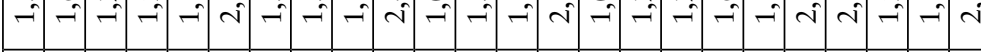

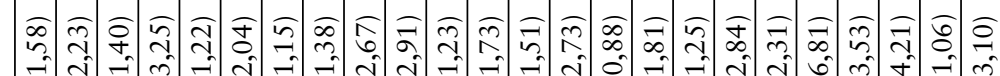

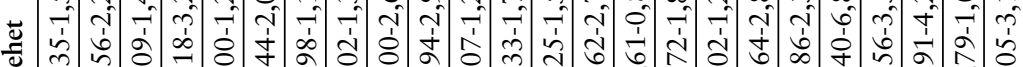

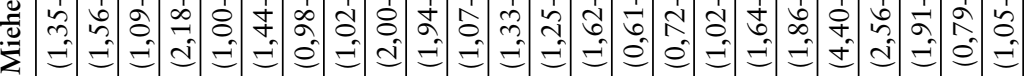

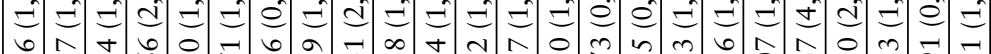

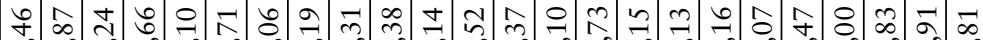

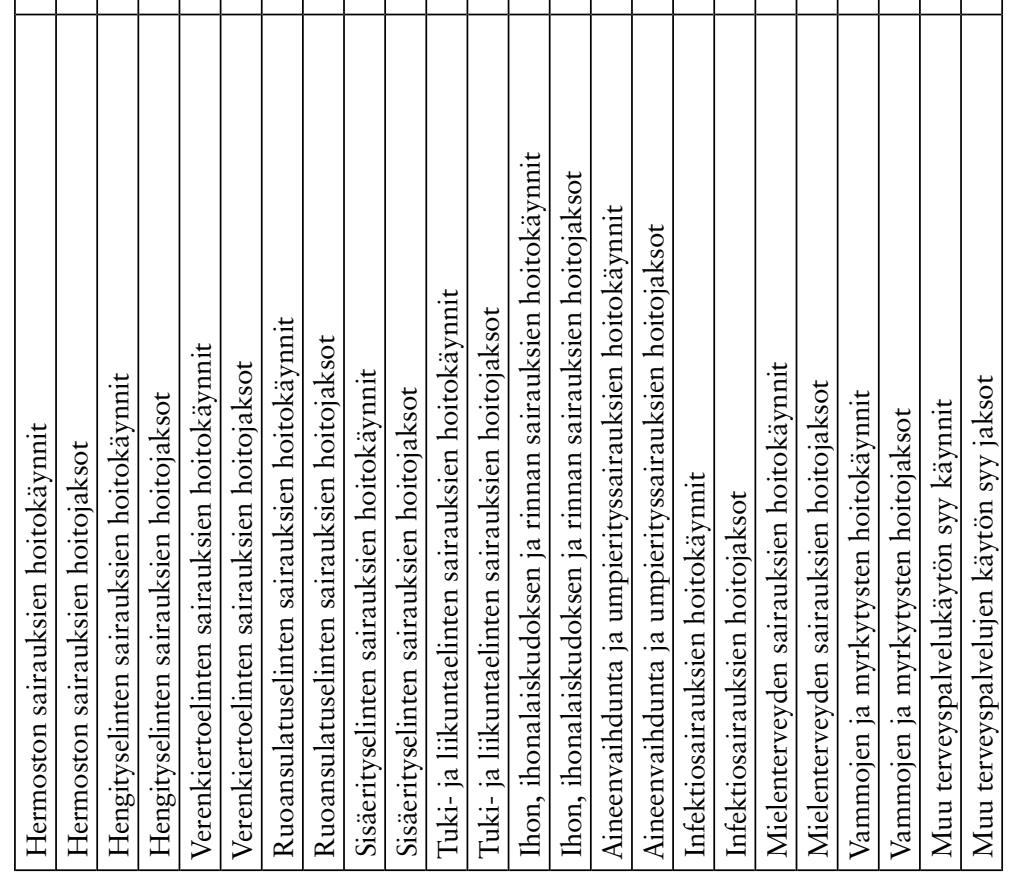




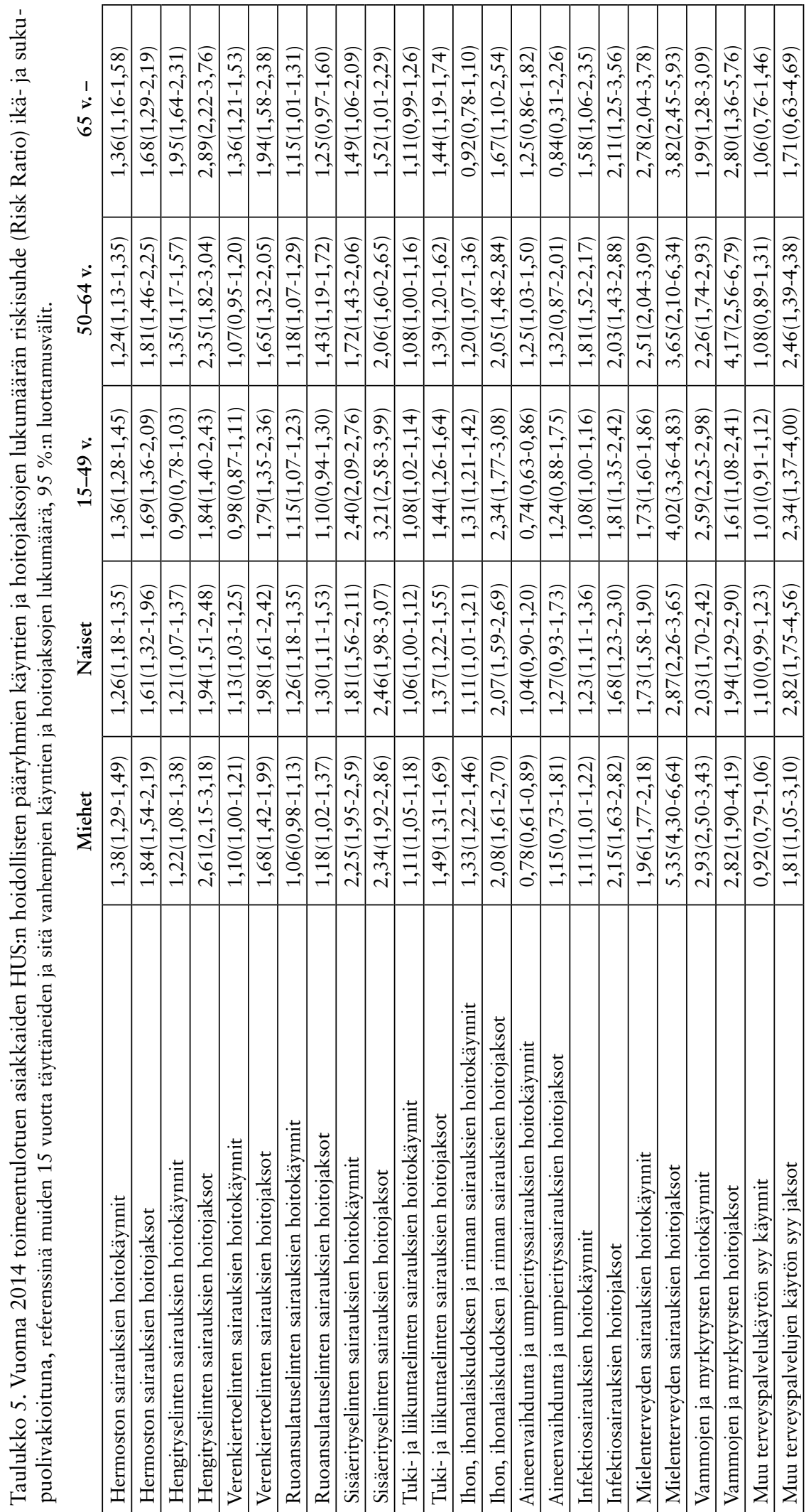




\section{POHDINTA}

Tulosten mukaan toimeentulotuen asiakkailla oli ikävakioituna lähes kaikkia yleisimpiä diagnoosiryhmiä yleisemmin kuin niillä terveyspalveluja käyttäneillä, jotka eivät olleet toimeentulotuen asiakkaita. Toimeentulotuen asiakkuus oli voimakkaimmin yhteydessä päihde- ja mielenterveysongelmiin. Toimeentulotuen asiakkuus oli yhteydessä perusterveydenhuollon käyntiin ja hoitojaksoon sekä käyntien ja hoitojaksojen lukumäärään. Voimakkaimmin toimeentulotuen asiakkuus oli yhteydessä päihdetyön ja psykiatrian yksiköiden käyntiin ja hoitojaksoon. Sen sijaan toimeentulotuen asiakkuus ei juuri ollut yhteydessä sosiaali- ja terveysviraston erikoislääkärivastaanottokäynnin toteutumiseen eikä suun terveydenhuollon käyntiin. Toimeentulotuen asiakkuudella oli yhteyttä useissa hoidollisissa pääryhmissä HUS:n erikoissairaanhoidon käynteihin ja hoitojaksoihin, mutta yhteys oli huomattavasti heikompaa kuin perusterveydenhuollon käynteihin ja hoitojaksoihin.

Tutkimuksen vahvuutena voidaan pitää sitä, että potilasasiakirjoja tietolähteenä käytettäessä vältyttiin asiakkaan muistiin liittyvästä mahdollisesta virhelähteestä, joka on mahdollinen kyselytutkimuksissa. Rekisteriaineisto kattoi helsinkiläisten käynnit lähes kaikissa Helsingin sosiaali- ja terveysviraston ja HUS:n yksiköissä vuoden 2014 aikana. Siten aineisto antoi luotettavan kuvan käyntien jakautumisesta tutkimusjoukossa.

Tutkimuksen heikkoutena oli se, että terveyspalvelujen tarve ei ollut vakioitavissa tällä rekisteriaineistolla. Terveyspalvelujen tarpeen mittaaminen olisi edellyttänyt kysely- tai terveystarkastusaineistoa. Kuitenkin toimeentulotukiasiakkailla oli yleisemmin jokin samana vuonna diagnosoitu sairaus kuin niillä, jotka eivät olleet toimeentulotuen asiakkaita. Toimeentulotuen asiakkuus selitti tilastollisesti merkitsevästi myös perusterveydenhuollon lisääntynyttä käyttöä, kun yleisimmät diagnoosit vakioitiin, mutta koska diagnoosin merkitsemisajankohtaa suhteessa terveyspalvelussa käyntiin tai hoitojaksoon ei voitu aineistosta poimia, ei tässä raportissa esitetty diagnoosimuuttujan sisältäviä tuloksia. Aikaisemmista tutkimuksista saatu näyttö kuitenkin antaa vahvoja viitteitä siitä, että alemmissa sosiaaliryhmissä olevilla on tarpeeseen nähden muita vähemmän terveydenhuollon kontakteja
(1,20,21,24). Myöskään tietoa toimeentulotuen ajoittumisesta suhteessa terveyspalvelujen käyttöön ei ollut, mutta toimeentulotuen asiakkuus kesti yleensä useamman kuukauden ajan ja noin joka kolmannella koko vuoden ajan.

Terveyspalveluissa rekisteröidään rakenteisesti hyvin vähän potilaiden sosiaalisia taustatietoja, ja sen vuoksi aineistossa oli vain sosiaalitoimen toimeentulotukiasiakkaista tiedot siviilisäädystä, asumismuodosta ja työssäkäynnistä. Tässä tutkimusaineistossa toimeentulotuen asiakkaista suurempi osuus oli työttömiä, eronneita, leskiä ja yksinasuvia sekä muuta kieltä kuin suomea tai ruotsia puhuvia kuin Helsingin väestöstä keskimäärin (26). Toimeentulotuen asiakkuus kokoaa yhteen monin tavoin muita heikommassa asemassa olevia henkilöitä.

Tulosten mukaan toimeentulotuen asiakkuus oli yhteydessä samana vuonna diagnosoituihin sairauksiin, kun ikä oli vakioitu. Toimeentulotuen asiakkaiden ikävakioitu kuolleisuus oli tämän tutkimuksen aineistossa suurempaa kuin niiden, jotka eivät olleet toimeentulotuen asiakkaita. Helsingissä peruspiirien välisistä kuolleisuuseroista miehillä yli kolmasosa ja naisilla vajaa kolmasosa johtuu alkoholi-, väkivalta- ja itsemurhakuolemista (27). Vuosina 1996-2005 Helsingissä peruspiirien välinen 20-vuotiaiden elinajanodotteen ero oli miehillä enimmillään 9,4 vuotta ja naisilla 5,6 vuotta, mutta vuosina 2005-2014 peruspiirien välinen ero vastasyntyneillä oli enimmillään miehillä 10,7 vuotta ja naisilla 6,2 vuotta (28). Toimeentulotuen asiakkaiden suhteellinen määrä erosi tuloksissa jyrkästi eri peruspiirien välillä.

Tutkimuksessa pyrittiin vastaamaan kysymyksiin, miten toimeentulotuen asiakkaiden perusterveydenhuollon käyttö eroaa muun väestön perusterveydenhuollon ja suun terveydenhuollon käytöstä ja miten toimeentulotuen asiakkaiden erikoissairaanhoidon käyttö eroaa muun väestön erikoissairaanhoidon käytöstä. Vaikka toimeentulotuen asiakkuus oli ikävakioituna yhteydessä lähes kaikkiin samana vuonna diagnosoituihin yleisimpiin diagnoosiryhmiin, toimeentulotuen asiakkuus oli yhteydessä vain muutamilla sosiaali- ja terveysviraston vastaanotoilla somaattiseen erikoislääkärivastaanottokäyntiin. Toimeentulotuen asiakkuus ei ollut miehillä eikä naisilla missään ikäryhmässä yhteydessä kardiologisiin vastaanottokäynteihin eikä rasitus-EKG-vastaan- 
ottokäynteihin. Miehillä toimeentulotuen asiakkuus selitti vähentynyttä gastroenterologisen vastaanottokäynnin, colonoskopiavastaanottokäynnin, diabetesvastaanottokäynnin ja elektiivisen kardioversion todennäköisyyttä. Tulos on samansuuntainen kuin eräiden aikaisempien tutkimusten tulos, jonka mukaan hyvätuloiset käyttävät erikoislääkärivastaanottoa pienituloisia enemmän (20,21,22). Tämän tutkimuksen tulokset perusterveydenhuollon palvelujen yleisemmästä ja lisääntyneestä käytöstä tukivat myös aiempien tutkimusten tuloksia $(11,20,21)$. Tutkimusten tulokset riippuvat kuitenkin siitä, oliko tutkimuksessa hoidon tarve vakioitu. Tarvevakioituna erikoissairaanhoidon palvelujen käyttö suosi hyvin toimeentulevia verrattuna pienitulosiin, mutta tarvevakioituna Suomessa hyvin toimeentulevilla on myös yleislääkärikäyntejä pienituloisia enemmän.

Toimeentulotuen asiakkuus oli yhteydessä HUS:n erikoissairaanhoidon käynteihin ja hoitojaksoihin joissakin hoidollisissa pääryhmissä. Toimeentulotuen asiakkuuden yhteys HUS:n erikoissairaanhoidon käynteihin ja hoitojaksoihin oli kuitenkin selvästi heikompi kuin sosiaali- ja terveysviraston perusterveydenhuollon käynteihin. HUS:n hoidollisista pääryhmistä toimeentulotuen asiakkuus selitti vammojen ja myrkytysten, hermoston sairauksien sekä infektioiden käyntejä miehillä ja sisäerityselinten ja ruoansulatuselinten sairauksien sekä infektioiden käynnin muita suurempaa todennäköisyyttä naisilla.

Tulosten mukaan toimeentulotuen asiakkuus oli molemmilla sukupuolilla ja eri ikäryhmillä yhteydessä lisääntyneisiin päihdeongelmiin ja mielenterveysongelmiin liittyviin käynteihin ja hoitojaksoihin, perusterveydenhuollon käynteihin ja akuuttihoitojaksoihin sekä päivystysvastaanottokäynteihin ja hoitojaksoihin. Toimeentulotuen asiakkaiden käynnit näissä yksiköissä olivat selvästi yleisempiä kuin muilla julkisen terveydenhuollon palvelujen käyttäjillä. Toimeentulotuen asiakkailla on todettu myös aiemmissa tutkimuksissa enemmän päihde- ja mielenterveysongelmia ja näiden palvelujen käyttöä kuin niillä, jotka eivät ole toimeentulotuen asiakkaita $(5,11)$.

Tulosten mukaan avosairaanhoidon lääkärin vastaanotolla ja aikuisten terveyskeskuspäivystyksessä kävi saman vuoden aikana 12,1\% toimeentulotuen asiakkaista ja 5,2\% niistä, jotka eivät olleet toimeentulotuen asiakkaita. Avosairaanhoidon lääkärin ja hoitajan vastaanottokäynti sekä aikuisten terveyskeskuspäivystyskäynti toteutui samana vuonna noin yhdeksällä prosentilla toimeentulotuen asiakkaista ja noin neljällä prosentilla niistä, jotka eivät olleet toimeentulotuen asiakkaita. Psykiatrian poliklinikkakäynti toteutui 3,5\%:lla toimeentulotuen asiakkaista ja 0,6\%:lla muista terveyspalveluja käyttäneistä. Kansallisen terveyspalvelujen käyttötutkimuksen mukaan noin 2,2 \% suomalaisista on käyttänyt psykiatrian poliklinikan tai mielenterveystoimiston palveluja (13). Tässä tutkimuksessa sekä psykiatrian poliklinikkakäynti että akuuttipsykiatrian hoitojakso toteutui 2,1\%:1la toimeentulotuen asiakkaista ja 0,3\%:1la niistä, jotka eivät ole toimeentulotuen asiakkaita. Keskimäärin vuodeosastohoidossa on vuoden aikana noin 13-14 \% kansalaisista (13.) Tämän tutkimuksen tulosten mukaan toimeentulotuen asiakkaista muuta väestöä suurempi osuus oli ollut perusterveydenhuollon akuuttihoitojaksolla, päivystyksen akuuttihoitojaksolla, kuntoutuksen laitoshoidossa ja akuuttipsykiatrian hoitojaksolla kuin muista helsinkiläisistä terveyspalvelujen käyttäneistä.

Tässä tutkimuksessa toimeentulotuen asiakkuus oli voimakkaasti yhteydessä päihde- ja mielenterveysongelmiin. Muun muassa yli vuoden työttömänä olleilla on todettu olevan sairauksia, joihin he eivät ole saaneet riittävästi hoitoa (29). Pitkäaikaistyöttömillä on todettu paljon hoitamattomia mielenterveyshäiriöitä (30), vaikka työttömänä olevat käyttävät muuta väestöä enemmän julkisen sektorin perusterveydenhuollon palveluja (31).

Yksityislääkärin käyttö on yleisintä ylimmissä tuloluokissa $(13,32)$. Toimeentulotuen asiakkaista noin $14 \%$, mutta muusta aikuisväestöstä runsas kolmannes käyttää vuoden aikana yksityislääkäripalveluja. Niillä, jotka eivät ole toimeentulotuen asiakkaita, on suhteellisesti noin kaksi kertaa toimeentulotuen asiakkaita yleisemmin vähintään yksi työterveyshuollon käynti vuoden aikana. Siten, koska yksityislääkärikäynnit ja työterveyshuollon käynnit eivät olleet mukana aineistossa, on todennäköistä, että muulla väestöllä oli todellisuudessa enemmän terveydenhuollon käyntejä kuin tämän tutkimuksen tulokset osoittavat. Tämän tutkimusaineiston ulkopuolelle jäi noin $23 \%$ 
toimeentulotuen asiakkaista ja $17 \%$ muista 15 vuotta täyttäneistä ja sitä vanhemmista helsinkiläisistä. Vuosina 2013-2015 helsinkiläisistä $36,2 \%$ oli vuoden aikana käyttänyt yksityislääkärin palveluja (33).

Terveydenhuollon käynnit ovat maassamme jo useita vuosikymmeniä jakaantuneet hyvätuloisia suosivasti, kun otetaan huomioon, että he tarvitsevat palveluja vähemmän kuin huonotuloiset.

Potilaalla on Suomessa verrattain suuri omavastuuosuus terveydenhuollossa ja esimerkiksi potilaan tuloja ei oteta huomioon sairaalamaksuissa (34). Aikuisväestön terveydenhuoltotutkimuksessa toimeentulotuen asiakkaista noin 20 prosenttiyksikköä muita suurempi osuus ilmoitti, että rahanpuute oli estänyt lääkärivastaanotolle hakeutumisen (13). Terveydenhuollosta potilaalle aiheutuvat kustannukset kuten palvelumaksut ja hoidosta johtuvat maksut eivät saisi estää palvelujen tarpeen mukaista käyttämistä.

Tämän tutkimuksen tulosten mukaan toimeentulotuen asiakkuus oli yhteydessä mm. lisääntyneeseen päivystysvastaanoton käyttöön. Aiemman tutkimuksen mukaan päivystyksen käyttöön ovat yhteydessä mm. oikea-aikainen pääsy terveysaseman vastaanotolle, ikä, sosioekonominen asema, ja potilaan työntekijän välinen vuorovaikutus (35). Lisäksi lisääntyneeseen päivystyksen käyttöön ovat yhteydessä myös kyky ymmärtää ja tulkita omaa terveyttä koskevaa informaatiota ja tehdä omia elintapoja, terveyttä ja terveyspalvelujen käyttöä koskevia päätöksiä (36). Terveyspalvelujen kehittämiseksi tarvitaan tietoja siitä, miten eri väestöryhmien kyky vastaanottaa, ymmärtää ja tulkita omaa terveyttään koskevia tietoja voidaan ottaa huomioon sekä miten voidaan auttaa eri väestöryhmiä tekemään elintapoja ja terveyspalvelujen käyttöä koskevia päätöksiä.

Jatkossa olisi selvitettävä, saavatko toimeentulotuen asiakkaat tarpeenmukaisia terveyspalveluja, erityisesti erikoissairaanhoidon palveluja. Jos heikossa sosiaalisessa asemassa olevat eivät saa tarpeenmukaisia terveyspalveluja, olisi selvitettävä, miksi he eivät niitä saa. Sosiaali- ja terveydenhuollossa niitä terveyspalveluja, joihin asiakkaalla on oikeus, ei ole määritelty yhtä tarkasti kuin esimerkiksi sosiaaliset etuudet. Toimeentulotuen käsittely siirtyi vuoden 2017 alusta kunnilta KELA:n hoidettavaksi. Ehkäisevä toimeentulotuki ja osa täydentävästä toimeentulotuesta jäävät edelleen kuntien hoidettavaksi. Helsingin sosiaali- ja terveysviraston kokemusten mukaan tämän muutoksen jälkeen tuen myöntämiskriteerit ovat kiristyneet ja perustoimeentulotuen asiakkaita on hakeutunut Helsingin sosiaali- ja terveysviraston asiakkaiksi. Tämän muutoksen vaikutuksia asiakkaiden palvelujen käyttöön olisikin jatkossa tutkittava.

\section{KIRJOITTAJIEN KONTRIBUUTIOT}

Nyman osallistui tutkimuksen suunnitteluun, tutkimusaineiston hankintaan ja käsittelyyyn sekä käsikirjoituksen laadintaan. Arffman osallistui tilastollisten menetelmien ohjaamiseen. Keskimäki toimi tutkimuksen ohjaajana.

Nyman, J., Arffman, M., Keskimäki, I. Income support and use of health services in Helsinki in 2014. Sosiaalilääketieteellinen aikakauslehti - Journal of Social Medicine 2017: 54: 310-326

People with poor socioeconomic status fall ill more often than others and have needs that are not met by health services despite the fact that they use basic healthcare services to a great extent (1). According to research, people with higher incomes are more likely to use specialised healthcare services than those in lower income brackets $(20,21)$. In this study, information about healthcare visits and treatment periods among people receiving income support $(\mathrm{N}=38,434)$ was compared with that of others who had used the services of the Social Services and Health Department and the Uusimaa Hospital District $(\mathrm{N}=401,231)$ and the relationship between receiving income support and visits to health services, treatment periods and the number of days spent in treatment was analysed using logistic regression analysis and the log-linear Poisson model. According to the results, health services customers receiving income support were clearly more likely to be diagnosed with an illness and to have a need for dental healthcare when adjusted for age. Receiving income support was closely connected to increased visits and treatment periods related to 
substance abuse and mental health issues, visits to basic healthcare and emergency health services, as well as acute treatment periods in basic health care and emergency services. However, receiving income support was less strongly connected to examinations from specialised practitioners and visits to dental health services, and for some specialised examinations, visits from people receiving income support were less likely relative to visits from other health services customers. Receiving income support was less strongly connected to visits to HUS than to visits to basic healthcare services provided by the Social Services and Health Department. Among HUS patients, receiving income support was correlated with visits for injuries and intoxication as well as diseases and infections of the nervous system among men, and with visits for diseases and infections of the internal excretory organs and digestive system among women. Persons receiving income support were most likely to undergo treatment periods at HUS for diseases of the internal excretory organs, the skin and subcutaneous tissue, the nervous system and the respiratory system.

Keywords: use of health services, income support, inequalities in health

\section{LÄHTEET}

1. van Doorslaer E, Wagstaff A, van der Burg H, ym. Equity in the delivery of health care in Europe and the USA. J. Health Econ. 2000;19:553-583. https://doi.org/10.1016/S0167-6296(00)00050-3

2. Kauppinen T, Moisio P, Mukkila S.

Toimeentulotuen saamisen toistuvuus ja etuuksien päällekkäisyys. Kirjassa: Kuivalainen S. (toim.) Toimeentulotuki 2010-luvulla THL-raportti 9/2013, 37-52.

3. Kuuden suurimman kaupungin toimeentulotuki vuonna 2014. Luettu 5.10.2016. http://www. kuusikkokunnat.fi/SIRA_Files/downloads/ TTT_2014_17062015.pdf

4. Kuivalainen S, Sallila S. Toimeentulotuen saajien köyhyys ja toimeentulotuen köyhyyttä vähentävä vaikutus 1990-2010. Kuivalainen S. (toim.) Toimeentulotuki 2010-luvulla. THL-Raportti 9/2013, 59-75

5. Mäkelä P, Kauppinen T, Huhtanen P. Alkoholihaitat vaivaavat huono-osaisia niin pääkaupunkiseudulla kuin muuallakin Suomessa. Yhteiskuntapolitiikka 2009;74 (2):185-194.

6. Mäkelä P. Alcohol related mortality as a function of socio-economic status. Addicton 1999;94 (6):867-886. https://doi.org/10.1046/j.13600443.1999.94686710.x

7. McCallum A, Manderbacka K, Arffman M, $\mathrm{ym}$. Socioeconomic differences in mortality amenable to health care among Finnish adults 1992-2003: 12 year follow up using individual level linked population register data. BMC Health Services Research 2013;13:3 Luettu 5.10.2016. http://bmchealthservres.biomedcentral.com/ articles/10.1186/1472-6963-13-3

8. Tchicaya A, Lorentz N. Socioeconomic inequalities in the non-use of dental care in Europe. Int J Equity Health 2014;13:7. Luettu 5.10.2016. Socioeconomic inequalities in the non-use of dental care in Europe I International Journal for Equity in Health I Full Text

9. Mäki N, Martikainen P. 2016. Kuolleisuus Helsingissä ja muualla Suomessa. Helsingin kaupungin tietokeskus. Tutkimuksia 5/2016. http://www.hel.fi/hel2/Tietokeskus/julkaisut/ pdff/16_11_08_Tutkimuksia_5_Maki_Martikainen. pdf. Luettu 2.2.2017

10. Sosiaali- ja terveysvirasto. Käyttösuunnitelma 2017. Helsingin kaupunki, sosiaali- ja terveysvirasto 13.12.2017. http:// dev.hel.fi/paatokset/media/att/ 0d/0d526b2fa379da692b9944160928052e8a99a 233.pdf

11. Hannikainen-Ingman K, Kuivalainen S, Sallila S. Toimeentulotuen asiakkaiden elinolot ja hyvinvointi. Kirjassa: Kuivalainen S. (toim.) Toimeentulotuki 2010-luvulla, THL, Raportti 9/2013, 81-112.

12. Aaltonen S, Berg P, Ikäheimo S. Nuoret luukulla, kolme näkökulmaa syrjäytymiseen ja nuorten asemaan palvelujärjestelmässä. Nuorisotutkimusverkosto/Nuorisotutkimusseura. Verkkojulkaisuja 84/2015. Luettu 5.10.2016.

13. Terveyspalvelujen käyttö ja sen väestöryhmittäiset erot 2006. Terveys 2000 -tutkimus.

Kansanterveyslaitoksen julkaisuja B10/2006. Luettu 3.1.2017.

14. Manderbacka K, Arffman M, Sund R, ym. Multiple social disadvantage does it have an effect on amenable mortality: a brief report. Int J Equity Health 2014;13:67.

https://doi.org/10.1186/s12939-014-0067-5

15. Lehikoinen M, Arffman M, Manderbacka K, ym. Comparative observational study of mortality amenable by health policy and care between rural and urban Finland: no excess segregation of mortality in the capital despite its increasing residential differentation. Int J Equity Health 2016;15:59. Luettu 10.10.2016.

16. van Doorslaer E, Wagstaff A, Bleichrodt H, ym. Income-related inequalities in health: some international comparisons. J Health Econ. 
1997;16:93-112.

https://doi.org/10.1016/S0167-6296(96)00532-2

17. Mackenbach J, Kunst A, Cavelaars A, ym. Socioeconomic inequalities in morbidity and mortality in Western Europe. The Lancet 1997;349 (7):1655-1659. https://doi.org/10.1016/S0140-6736(96)07226-1

18. Manderbacka K, Järvelin J, Arffman M, ym. The development of differences in hospital costs accross income groups in Finland from 1998 to 2010. Health Policy 2014;118:354-362. https://doi.org/10.1016/j.healthpol.2014.07.015

19. Manderbacka K, Järvelin J, Arffman M, ym. National and regional trends in equity within specialised health care in Finland in 2002-2010. Scand J Public Health 2015; 43:514-517. https://doi.org/10.1177/1403494815585615

20. van Doorslaer E, Masseria C, Koolman X, ym. Inequalities in access to medical care by income in developed countries. CMAJ 2006;174(2):177-83. Luettu 5.10.2016. Inequalities in access to medical care by income in developed countries

21. Devaux M, de Looper M. Income-Related Inequalities in Health Service Utilisation in 19 OECD Countries, 2008-2009, OECD Health Working Papers, No. 58, OECD Publishing. Luettu 5.10.2016.

22. Manderbacka K, Arffman M, Karvonen S, ym. Huono-osaisuus terveydenhuollossa: Sosioekonomiset erot elektiivisessä kirurgiassa. Suomen Lääkärilehti 2008;22 (63):2025-2031.

23. Manderbacka K, Arffman M, Leyland A, ym. Change and persistence in healthcare inequities: Access to elective surgery in Finland in 1992-2003. Scand J Public Health 2009;37:131-138. https://doi.org/10.1177/1403494808098505

24. Kallio J, Kallio J, Pesonen T, ym. Hammashoitopalvelujen käyttämättömyys. Voiko syynä olla muutakin terveet hampaat? Yhteiskuntapolitiikka 2013;78 (1):20-34.

25. Manderbacka K., Arffman M., Keskimäki I. Has socioeconomic equity increased in somatic specialist care: a register-based cohort study from Finland in 1995-2010. BMC Health Services Research 2014;14:430 http://www.biomedcentral. com/1472-6963/14/430 https://doi.org/10.1186/1472-6963-14-430

26. Helsingin väestö vuodenvaihteessa 2014/2015 ja väestömuutokset 2014. Helsingin kaupungin tietokeskus. Tilastoja 21/2015. http://www. hel.fi/hel2/tietokeskus/julkaisut/pdf/15_07_02_ Tilastoja_21_Maki\%26VuoriP.pdf

27. Valkonen T, Martikainen P, Kauppinen T, ym. Elinajanodotteen kehitys Helsingissä ja sen väestön osasryhmissä 1991-2005. Helsingin kaupungin tietokeskus. Tutkimuksia 2/2008.

28. Mäki N. New Yorkissa Elinajanodote voimakkaasti yhteydessä alueen tulotasoon-entä Helsingissä? Kvartti Verkkolehti 11.11.2015.
Luettu 5.10.2016. http://www.kvartti.fi/fi/blogit/ new-yorkissa-elinajanodote-voimakkaastiyhteydessa-alueen-tulotasoon-enta-helsingissa

29. Nyman J, Häkkinen U, Alha P, ym. Differences in the patterns of primary health care use. Kieselbach T. Mannila S. (toim.) Unemployment, Precarious Work and Health, Research and Policy Issues. pp. 305-320. VS Verlag.

30. Kerätär R, Karjalainen V. Pitkäaikaistyöttömillä on runsaasti hoitamattomia mielenterveyshäiriöitä. Suomen Lääkärilehti 2010;45:3683-3690.

31. Virtanen P, Kivimäki M, Vahtera J, ym. Employment status and differences in the one-year coverage of physician visits: different needs or unequal access to services? BMC Health Services Research 2006;6:123. Luettu 5.10.2016.

32. Kallio J. Yksityisten lääkäripalvelujen käyttö ja ideologiset tekijät. Yhteiskuntapolitiikka 2008;73(5):477-493.

33. Kaikkonen R, Murto J, Pentala O, ym. Alueellisen terveys- ja hyvinvointitutkimuksen perustulokset 2010-2015. Verkkojulkaisu: Taulukot - ATH Terveytemme

34. Sosiaali- ja terveydenhuollon monikanavarahoituksen purkamisen vaihtoehtoja koskeva selvitys. Sosiaali- ja terveysministeriön raportteja ja muistioita 2015:19. Luettu 5.10.2016. https://www. julkari.fi/bitstream/handle/10024/125789/URN_ ISBN_978-952-00-3579-2.pdf? sequence=1

35. Cowling T, Cecil E, Soljak M, ym. (2013) Access to Primary Care and Visits to Emergency Departments in England: A Cross-Sectional, Population-Based Study. PLoS ONE 8(6): e66699. doi:10.1371/journal.pone.0066699. Luettu 10.10.2016. https://doi.org/10.1371/journal.pone.0066699

36. Schumacher J, Hall A, Davis T, ym. Potentially preventable use of emergency services: the role of low health literacy. Medical Care 2013;51 (8):654-658. Luettu 5.10.2016.

\section{JuHa Nyman}

FT, erityissuunnittelija

Helsingin kaupunki

Helsingin sosiaali- ja terveystoimi

MartTi Arffman

VTM, tilastotukija

Terveyden ja hyvinvoinnin laitos

Sosiaali- ja terveydenhuollon tutkimusyksikkö

\section{ILMO KESKIMÄKI}

LT, dosentti, tutkimusprofessori

Terveyden ja hyvinvoinnin laitos

Tampereen yliopisto

Terveystieteiden yksikkö 